\title{
STRATEGI PEMBELAJARAN KOSAKATA BAHASA ARAB BAGI NON ARAB
}

\author{
Abdurochman \\ Universitas Islam Negeri Raden Intan \\ Email:armanrohman96@yahoo.co.id
}

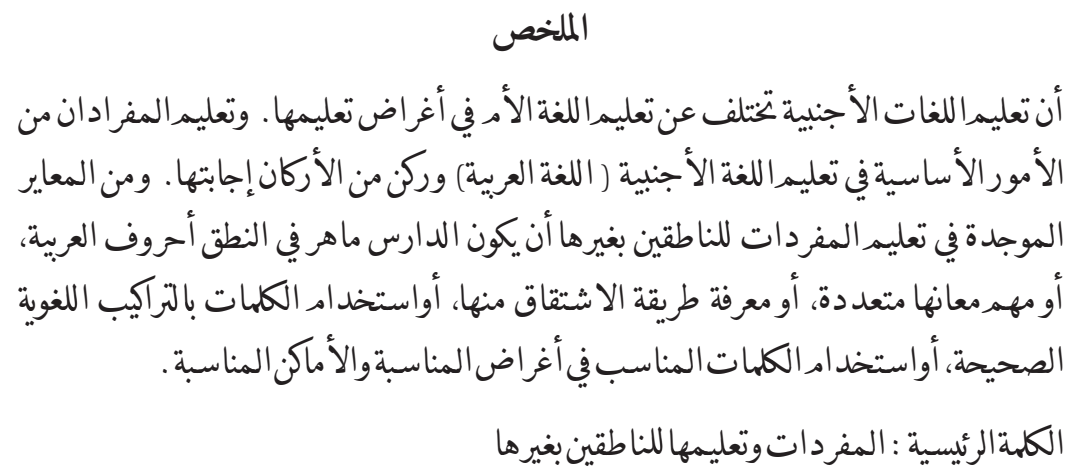

\begin{abstract}
Abstrak
Dalam pembelajaran bahasa-bahasa Asing berbeda dengan pembelajaran bahasa Ibu hal ini dapat dilihat dari segi tujuan pembelajarannya. Pembelajaran koskata bahasa Arab merupakan hal yang primer dan harus direalisasikan. Adapun penilaian yang harus diperhatikan dalam pembelajaran koskata bahasa Arab adalah sebagai berikut: seorang peserta didik dituntut dalam ketepatan mengucapkan huruf-huruf Arab, peserta didik dapat menggetahui aneka ragam makna yang terdapat dalam bahasa Arab, peserta didik dapat mengtahaui fenomena istiqaq, peserta didik mampu menggunakan kalimat-kalimat bahasa Arab dengan grametikal
\end{abstract}


Arab, peserta didik mampu menggunakan kalimat-kalimat bahasa Arab yang sesuai dengan situasi, kondisi dan tujuan yang dimaksud.

Kata Kunci:Koskata dan Pembelajaranya bagi non Arab

\section{A. Pendahuluan}

Belajar Bahasa Arab berbeda dengan belajar bahasa Indoneisa, oleh karena itu prinsip dasar pengajarannya harus berbeda, baik menyangkut metode (model pengajaran), materi bahan ajar maupun proses pelaksanaan pengajarannya. Bidang keterampilan pada penguasaan bahasa Arab meliputi kemampuan menyimak (listening competence/ mahaarah al - Istima'), kemampuan berbicara (speaking competencel mahaarah al-takallum), kemampuan membaca (reading competencel mahaarah al-qira'ah), dan kemampuan menulis (writingcompetence/ mahaarah al - Kitaabah).Unsur bahasa Arab mencakup empat tingkatan al-mufradât (kosakata), al-ashwat(fonologi), al-sharf (morfologi) al-nahwu (sintaksis).

Mamduh Nur al-Din dalam Mudzakkarah fi Tadris al-Mufradat mengatakan bahwa mufradat (koskata) adalah aspek vital dalam bahasa Arab.Alasannya karena bahasa Arab memiliki banyak aspek, antara lain bunyi-bunyi, bangunan kata-kata, susunan kalimat, dan makna. ${ }^{1} \mathrm{Oleh}$ karenanya jenjang pembelajarankosa kata bahasa Arab hendaknya mempertimbangkan dari aspek penggunannya bagi siswa, yaitu diawali dengan memberikan materi kosa kata yang banyak digunakan dalam keseharian berupa kata dasar.Selanjutnya memberikan materi kata sambung. Hal ini dilakukan agar siswa dapat menyusun kalimat sempurna sehingga terus bertambah dan berkembang kemampuannya.

1 Acep Hermawan, Metodologi Pembelajaran Bahasa Arab, (Bandung: Remaja Rosdakarya, 2014), h. 270. 
Jumlah kosakata (mufradat) yang diajarkan, ada berbedaan pendapat tentang jumlah mufradat yang diajarkan kepada siswa pada program pembelajaran bahasa Arab untuk non Arab antara yang mengusulkan berjumlah antara 750 samapi 1000 kasokata untuk tingkat pemula, 1000 sampai 15000 kosakata untuk tingkat lanjutan dan 1500 sampai dengan 2000 kosakata untuk tingkat atas. Ada pula yang berpendapat bahwa 2000 atau 2500 kosakata pada tingkat ibtida' cukup bagi mereka dengan syarat belajar menyusun kalimat dan terampil menggunakan kamus. ${ }^{2} P e n g a y a a n$ kosakata sangat lah penting, apalagi dalam konteks pengajaran bahasa Arab bagi non Arab.Hal ini dapat dirasakan ketika siswa mempelajari bahasa Arab melalui buku bahan ajar yang telah ditentukan oleh guru. Kebutuhan koskata ini sejatinya tidak hanya bagi orang Asing non Arab, melaikan juga dalam pengajaran bahasa Arab untuk orang Arab sendiri.

\section{B. Prinsip-prinsip Pembelajaran Bahasa Arab}

Dalam pembelajaran bahasa Arab ada beberapa prinsip yang harus diperhatikan oleh guru bahasa Arab dan pemerhati bahasa Arab dengan harapan pembelajaran bahasa Arab menjadi pembelajaran yang terkesan mudah dan menyenangkan. Diantara prinsip pembelajaran bahasa Arab sebagai berikut:

Prinsip Prioritas (الأوليات) dalam penyajian keterampilan bahasa Arab yang harus diprioritaskan yaitu; Pertama,mengajarkan mendengar, berbicara sebelum membaca dan menulis. Kedua,mengajarkan kalimat sebelum kata. Ketiga, menggunakan kata-kata yang lebih familiyer dalam aktifitas sehari-hari sebelum mengajarkan bahasa sesuai dengan penutur bahasa Arab langsung.

2 Bisri Mustafa dan Abdul Hamid, Metode\&Strategi Pembelajaran Bahasa Arab,( Malang: UIN Malang Press, 2012, cetakan II, h. 70. 
Prinsip Korektisitas (الذقة) prinsip ini digunakan kitaka mengajarkan materi fonetik.Morfologi dan sintaksis dan semantik. Tujuan dalam prinsip ini seorang guru bahasa Arab dituntut tidak hanya menyalahkan siswa, tetapi guru harus mampu melakukan koreksi dan menumbahkan sikap kritis kepada siswa diantaranya adalah: Pertama, koretisitas dalam mengajarkan (fonetik). Kedua, korektisitas dalam mengajarkan (sintaksis), ketiga korektisitas dalam mengajarkan (semantik).

Prinsip Berjenjang ( التدرج) dalam pembelajaran bahasa Arab, ada tiga kategori prinsip berjenjang, yaitu: Pertama, pergeseran dari yang konkrit ke yang abstrak, dari yang global ke yang detail, dari yang sudah diketahui ke yang belum diketahui. Kedua, ada kesinambungan antara apa yang telah diberikan sebelumnya dengan apa yang akan ia ajarkan selanjutnya. Ketiga, ada peningkatan bobot pengajaran terdahulu dengan yang selanjutnya, baik jumlah jam maupun materinya.

Prinsip Kerinduan (التشويق) yang dimaksud kerinduan disini adalah; menghadirkan berbagai macam pendekatan, metode, strategi dan teknik dalam pembelajaranya, dengan tujuan menjadikan proses maupun kegitan belajar mengajar menyenangkan dan tidak menjadikan siswa bosan. Hakekat bahasa adalah praktek dan kebiyasaan dalam mendengar, berbicara, membaca dan menulis.

\section{Orentasi Pembelajaran Bahasa Arab}

Masyrakat Badui memiliki kontribusi yang berharga bagi pertumbahan dan perkembangan bahasa Arab, mereka merupakan masyrakat pedalaman Arab dan belum mengenal peradaban secara luas, bahasa mereka pun masih terjaga keaslianya.Semenjak datangnya Islam perkembangan bahasa Arab pun terus berkembang dengan pesat. Islam terus tersebar di seluruh Jazirah Arab begitu juga dengan daerahdaerah di Asia Tengah dan Selatan dan beberapa wilayah Eropa.Pada 
masa Umaiyah bahasa Arab dijadikan sebagai bahasa pemerintahan dan administrasi negara (surat menyurat, komunikasi, tulis-menulis dan lain-lain). Bahasa Arab semakin lama semakin berkembang pada masa Abbasyiah hal ini dibuktikan dengan ekspansi di luar jazirah Arab. Pada masa Abbasyiah dalam pembelajaran bahasa Arab mereka memanggil orang Badui untuk datang ke istana langsung hal ini berbeda pada masa Umaiyah yang belajar langsung kepada orang Badui yang tinggal di pedalaman. Pada masa Abbasyiah bahasa Arab mengalami tantangan luar biyasa dengan munculnya bahasa ammiyyah (bahasa daerah) yang dipakai oleh penduduk yang berada di bawah kekuasaan Islam.

Bahasa Arab sudah diajarkan di Indonesia sejak Islam masuk ke Nusantara, ketika itu bahasa Arab diajarkan untuk memahami dan mendalami syariat islam melalui kitab suci al-Qur'an karim dan hadits nabawi, yang keduanya merupakan sumber ajaran islam yang ditulis dengan bahasa Arab. Oleh karenanya, memahami dan mendalami bahasa Arab adalah sebuah keharusan.

Eksisitensi pembelajaran bahasa Arab pada saat ini mengalami perkembangan dan reorentasi hal ini dibuktikan dengan adanya pembelajaran bahasa Arab untuk tujuan tertentu seperti: pembelajaran bahasa bagi TKI (Tenaga Kerja Indonesia), diplomat, perdagangan, pariwisata dan masih banyak lagi.

Pembelajaran bahasa Arab di Indonesia dikenalkan dan diajarkan dari TK (Taman Anak-Anak), sampai perguruan tinggi baik negri maupun swasta.Bahasa Arab kini menjadi bahasa dunia internasional setelah Spanyol, memiliki andil besar dalam menumbuh kembangkan ilmu pengetahuan dan teknologi modern. ${ }^{3}$ Orentasi pembelajaran bahasa

3 Zulhanan, Teknik Pembelajaran Bahasa Arab Interaktif, (Depok: Raja Grafindo Persada, 2014, cetakan I) h.108. 
Arab terus berkembang tidak hanya sebatas memahami teks agama akan tetapi lebih dari pada itu. Diatara orentasi adalah sebagai berikut:

1. Orientasi religius, yaitu belajar bahasa Arab untuk tujuan memahami dan memahamkan ajaran Islam (fahm al-maqru'). Orientasi ini dapat berupa belajar keterampilan pasif (mendengar dan membaca), dan dapat pula mempelajari keterampilan aktif (berbicara dan menulis).

2. Orientasi akademis, yaitu belajar bahasa Arab untuk tujuan memahami ilmu-ilmu dan keterampilan berbahasa Arab (istimâ, kalâm, qirầah, dan kitâbah). Orientasi ini biasanya identik dengan studi bahasa Arab di Jurusan Pendidikan Bahasa Arab, Bahasa dan Sastra Arab, atau pada program Pascasarjana dan lembaga ilmiah lainnya.

3. Orientasi profesional/praktis dan pragmatis, yaitu belajar bahasa Arab untuk kepentingan profesi, praktis atau pragmatis, seperti mampu berkomunikasi lisan (muhâdatsah) dalam bahasa Arab untuk bisa menjadi TKI, diplomat, turis, misi dagang, atau untuk melanjutkan studi di salah satu Negara Timur Tengah, dan sebagainya.

4. Orientasi ideologis dan ekonomis, yaitu belajar bahasa Arab untuk memahami dan menggunakan bahasa Arab sebagai media bagi kepentingan orientalisme, kapitalisme, imperialisme, dan sebagainya. Orientasi ini antara lain, terlihat dari dibukanya beberapa lembaga kursus bahasa Arab di negara-negara Barat. ${ }^{4}$

Bahasa Arab merupakan bahasa Manusia atau produk budaya bangsa Arab.Ia bukan bahasa Tuhan ataupun Malikat. Meskipun kalama Allah

4 Acep Hermawan, Metodologi Pembelajaran Bahasa Arab, (Bandung: Remaja Rosdakarya, 2014), h. 89. 
(al-Qur'an) diwahyukan kepada Nabi Muhammad SAW dalam bahasa Arab.Maka sebagi prodak dan sistem budaya, bahasa Arab mempunyai demensi akademik, humanistik, dan pragmatik.Ia tunduk kepada sistem lingustik yang telah menjadi kesepakatan penutur bahasa ini, baik sistem fonologi (aswat), morfologi (sharaf), sintaksis (nahwu) dan sematik (dalalah). ${ }^{5}$ Oleh karenaya objek kajian bahasa Arab sangat menarik dan dinamis baik dari aspek pendidikan bahasa Arabnya, aspek kebahasaanya, aspek sosiolingustiknya, pisokolingustiknya dan masih banyak lagi.

\section{Defenisi Mufradat (Kosakata)}

Kosakata dalam bahasa Arab disebut mufradat, dalam bahasa Inggrisnya vocabulary adalah himpunan kata atau khzanah kata yang diketahui oleh seseorang atau etnis lain yang merupakan bagian dari suatu bahasa tertentu.Menurut Horn, kosakata adalah sekumpulan kata yang membentuk sebuah bahasa. Peran kosakata dalam menguasai emapat kemahiran berbahasa sangat diperlukan sebagaimana yang dikemukakan oleh Vallet adalah bahwa kemampuan untuk memahami empat kemahiran berbahasa tersebut sangat tergantung pada penguasaan kosakata seseorang. ${ }^{6}$ Kosakata (mufradat) jamak dari mufradaat yang dalam bahasa Inggrisnnya: Vocable, Word; Term, names, expressions (of a Scientific field); details. ${ }^{7}$ Dalam kamus besar bahasa Indonesia dijelaskan bahwakosakata(mufradat) adalah semua kata yang terdapat dalam suatu

5 Muhbib Abdul Wahab, Pemikiran Lingustik Tammam Hassan dalam Pembelajaran Bahasa Arab, (Jakarta: UIN Jakarta Press, 2009),h. 23.

${ }^{6}$ Edison de Cunha, Developing English Teaching Materials For Vocabulary of First Grade of Junior High School,h.3.

7 Hans Wehr, A, Dictionary of Modern Written Arabic, Arabic-English, Beirut: Makatabah Lubnan, Cetakan III, h. 704. 
bahasa; perbendaharaan kata; kosakata, atau daftar kata diurutankan per abjad yang biasanya disertai dengan dengan makna atau terjemahan. ${ }^{8}$

Kata merupakan satuan bahasa terkecil yang berdiri sendiri. Defenisi ini menjelaskan perbedaan antara kata dan morfem.Morfem adalah satuan bahasa terkecil yang mempunyai makna.Oleh karena itu, terkadang morfem bisa berdiri sendiri terkadang juga terikat. Sebagai contoh kata معلّ terdiri dari satu morfem, sedangkan المعلمّلم terdiri dari dua morfem yaitu IJ dan معلّم Dan kata المعلمّون terdiri dari tiga morfem yaitu

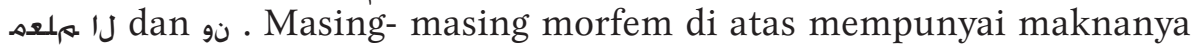
sendiri.Disamping itu, kata terkadang berupa kata dasar, terkadang juga kata berimbuhan.Jika berimbuhan, kata itu mempunyai akar karta atau kata dasar memiliki satu imbuhan atau lebih. Kata makar katanya

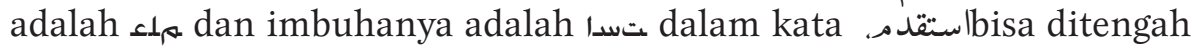
yang disebut sisipan seperti قادم pada kata قادم ba juga di belakang

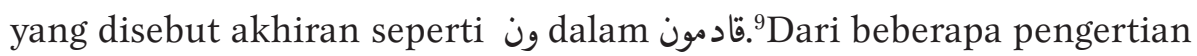
kosakata (mufradat) diatas, dapat ditarik kesimpulan bahawa kosakata (mufradat) adalah merupakan kumpalan kosakata yang lazim digunakan oleh seseorang baik secara lisan maupun tulisan yang sudah memiliki pengertian dan penjelesana dari hasil terjemahannya.

Dalam konteks pembelajaran kosakata sebaiknya guru mengajarkan muridnya agar memperhatikan unsur-unsur pembentukan kata termasuk imbuhan: awalan, sisipan, dan akhiran, karena imbuhan merupakan morfem yang memiliki makna yang sangat sering ditemukan dalam bahasa kita termasuk bahasa Arab. Jika siswa memahami makna masingmasing imbuhan ini, maka ia akan mudah memahami makna kata-kata yang lain. Apalagi kalau mengerti makna kata dasarnya.Dalam hal ini,

8 Dep Dik Bud, Kamus Besar Bahasa Indonesia, (Jakarta: Balai Pustaka, 1990, cetakan III), h.104.

9 Muhamd Ali Al-Khuli, Strategi Pembelajaran Bahasa, (Yogyakarta: Bansam Publishing, 2010, cetakan II), h. 87. 
harus memperhatikan tingkatan satuan pendidikan dan kecerdasan peserta didik.

\section{E. Hal-hal yang Harus Diperhatikan dalam Memilih Strategi Pembelajaran Kosakatabahasa Arab}

Sebelum membahas strategi pembelajaran kosakata bahasa Arab bagi non Arab, terdapat beberapa hal yang harus diperhatikan di sini yaitu latar belakang dalam memilih strategi yang akan digunakan.Adapun latar belakang yang harus diperhatikan dalam memilih stratrgi pembelajaran kosakata bahasa Arab bagi non Arab adalah sebagai berikut: motivasi, latar belakang pendidikan peserta didik, waktu, media pembelajaran dan evaluasi.

\section{Motivasi}

Sebelum memilih strategi pembelajaran kosakata bahasa Arab. Seorang pendidik terlebih dulu hendaknya memperhatikan motivasi peserta didik. Karena tidak sedikit dari peserta didik yang tidak memililikibasic yang memadai.

\section{Latar belakang siswa}

Yang tidak kalah pentingnya bagi guru dalam memilih strategi pembelajaran kosakata ini adalah melihat kepada latar belakang peserta didik. Penguasan kosakata bahasa Arab sangat membatu dalampenguasaan keterampilan mendengar, berbicara, membaca dan menulis.

Basic lulusan pesantren tentunya berbeda dengan lulusan bukan dari pesantren. Disini peran guru sangat dominan untuk dapat mengarahkan peserta didiknya, membina dan meningkatkan motivasi mereka untuk menguasai kosakata bahasa Arab.Oleh sebab itu, guru 
dituntut untuk selektif memilih strategi dengan memperhatikan latar belakang peserta didik sehingga motivasi mereka dapat diarahkan dan dikembangkan.

\section{Waktu}

Sebelum guru menentukan strategi dalam pembelajaran kosakata bahasa Arab yang perlu diperhatikan adalah alokoasi waktu, baik waktu yang yang berkaitan dengan kegiatan belajar mengajar di sekolah mapun waktu pertemuan/tatap muka dengan peserta didik. Urgensi pembelajaran sering tidak terealisasi dikarenakan ketidak jelasan dalam pembagian waktu pada strategi yang diterapkan.

\section{Media pembelajaran}

Media memiliki beberap keunggulan diantaranya dapat mempermudah guru dalam menyampaikan materi bahan ajar sekaligus dapat memotivasi peserta didik.Adanya kesesuian dalam menggunakan strategi pembelajaran kosakata bahasa Arab dengan harpan pembelajaranya bisa terarah.

\section{Evaluasi}

Untuk mengukur kemampuan bahasa peserta didik, tingkat keberhasilan dan tercapainya tujuan pembelajaran kosakata bahasa Arab adalah dengan cara evaluasi. Evaluasi dalam meteri kosakata yang perlu diperhatikan adalah kemampuan siswa untuk melafalkan kata, menulis kata, meyusun kata dan lain sebagainya.Aspek evaluasi ini lebih menekankan kepada hasil siswa.

Dimikian juga terdapat hal-hal yang penting dalam pengajaran mufradat.(1) Pengajaran mufradat tidak berdiri sendiri. (2) Pembatasan waktu. (3) kosakata dalam konteks. (4) Terjemahan dalam mengajarkan koskata. (5) Tingkat kesukaran.Mufradat tidak diajarkan sebagai mata 
pelajaran yang berdiri sendiri mlainkan terkait dengan pengajaran muthala'ah, istima, insya, dan Muhadatsah.

Suatu kata dapat mempunyai beberapa makna.Hal ini merupakan kesulitan tersendiri bagi para pembelajar bahasa asing.Dalam hubunggan ini, untuk para pemula, sebaiknya guru hanya mengajarkan makna yang sesuai dengan konteks saja, agar tidak memecah perhatian dan ingatan siswa.Untuk tingkat lanjut, penjelasan makna bisa dikembangkan, dengan memberikan contoh dalam kalimat-kalimat, agar para siswa memiliki wawasan yang luas mengenai makna kata tersebut.

Banyak kosakata yang tidak bisa dipahami secara tepat mengetahui pemakaiannya dalam kalimat.Kosakata semacam ini haruslah diajarkan dalam konteks agar tidak mengacaukan pemahaman siswa.

Mengajarkan makna kata dengan cara menerjemahkannya ke dalam bahasa ibu adalah cara yang paling mudah, tetapi mengandung beberapa kelemahan, antara lain bisa menggurangi sepontanitas siswa ketika menggunakannya dalam ungkapan, lemah daya lekatnya dalam inggatan siswa, dan tidak semua kosakata bahasa asing terdapat padanannya yang tepat dalam bahasa ibu. Oleh karena itu menerjemah direkomendasikan sebagai cara terakhir, kecuali untuk kata-kata yang abstrak atau sulit diperagakan. ${ }^{10}$ Perlu disadari bahwa kosakata bahasa Arab bagi siswa Indonesia dapat dibedakan menjadi tiga, ditinjau dari tingkat kesukarannya:

a) Kata-kata yang mudah, karena ada persamaannya dengan kataرمة، كرسي، كاب، علماء kata dalam bahasa Indonesia, seperti

b) Kata-kata yang tidak sukar meskipun tidak ada persamaanya مدينة، سوف، ذهب : مalam bahasa Indonesia, seperti

${ }^{10}$ Ahmad Fuad Efendy, Metodologi Pengajaran Bahasa Arab, (Malang: Miskat, 2012, cetakan V), h. 128 . 
c) Kata-kata yang sukar, baik karena bentuknya maupun استبقى، استولى، تدهور. pengucapannya, seperti:

Tidak diragukan lagi bahwa hal yang sulit dihadapi oleh guru bahasa asing termasuk bahasa Arab adalah cara menyampaikan beberapa kosakata baru dan menjelaskannya di depan siswa. Oleh karena itu perlu adanya strategi dalam menyampaikan kosakata yang tepat, efektif dan efesien.Mufradat (kosakata) sebagai salah satu bagian penting dari komponen bahasa, baik secara liasan maupun tulisan, dan merupakan salah satu basis pengembangan kemampuan berbahasa Arab. ${ }^{12}$

Diantara tujuan utama pembelajaran mufradat bahasa Arab adalah sebagai berikut: (a) Memperkenalkan kosakata baru kepada siswa maupun mahasiswa, baik melalui bahan bacaan maupun fahm al-Masmu? (b) Melatih peserta didik maupun mahasiswa untuk dapat melafalkan kosakata itu dengan baik dan benar karena melafalkan yang baik dan benar mengantarkan kepada kemahiran berbicara dan membaca secara baik dan benar pula. (c)Memahami makna kosakata, baik secara denotatif atau leksikal (berdiri sendiri) maupun ketika digunakan dalam konteks kalimat tertentu (makna konotatif dan grametikal). (d) Mampu mengapresiasi dan mengfungsikan mufradaat itu dalam berekspresi lisan (berbicara) maupun tulisan (mengarang) sesuia dengan konteksnya yang benar. ${ }^{13}$

Uril Bahrudin menjelaskan dalam bukunya Bisa Bahasa Arab Bukan Hanya Mimpi terkait target yang inggin dicapai dalam bembelajaran mufradat bukan sekedar memahami artinya, namu ada enam hal yang harus diperhatikan oleh siapa saja yang mau belajar mufradat. (1) Dapat

\footnotetext{
${ }^{11}$ Ahmad Fuad Efendy, Metodologi Pengajaran Bahasa Arab, h. 129.

${ }^{12}$ Abdul Hamid, Mengukur Kemampuan Bahasa Arab untuk Studi Islma, (Malang: UIN Malik Press 2010, cetakan I), h.33.

${ }^{13}$ Muhbib Abdul Wahab, Epistemologi dan Metodologi Pembelajaran Bahasa Arab, (Jakarta: Lembaga Penelitian UIN Syarif Hidayatullah Jakarta 2008, cetakan I), h. 152.
} 
mengucapkan mufradat dengan benar, (2) dapat mengetahui makananya, (3) dapat menggunakanya dalam kalimat, (4) dapat menggunakannya dalam konteks yang tepat, (5) dapat mengeja dan menulisnnya, dan (6) dapat mengetahui asal-usul kata atau derivasinya. ${ }^{14}$

\section{F. Kriteria yang Harus Diperlukan dalam Proses Seleksi Kokata}

Seleksi kosakata bahasa Arab sangat diperlukan bagi guru bahasa Arab, karena dalambahasa memiliki ratusan ribu kosakata, sebagaimana bahasa asing lainya. Peserta didik yang inggin mempelajari bahasa Arab tidak mungkin mengusai seluruh kosakatanya, akan tetapi ia cukup mempelajari dan menggusai ratusan atau ribuan kosakata saja. Berikut ini adalah kriteria yang harus diperhatikan dalam proses seleksi koskata.

1. Kriteria tingkat kedekatan: Kriteria ini memprioritaskan kosakata yang berhubungan dengan lingkungan sekitar siswa seperti kosakata yang berkaitan dengan lingkungan kelas, sekolah dan rumah.

2. Kriteria kemudahan: Kriteria ini memprioritaskan kosakata baku yang tidak meragukan atau kata-kata yang tidak memiliki kesulitan pengucapan ataupun penulisan.

3. Kriteria manfaat: Sebagai ahli perpendapat bahwa kriteria seleksi kosakata harus bertolak dari tingkat kebutuhan siswa akan kata-kata tersebut dengan tidak memperhatihakan kriterian kedekatan atau kemudahan. ${ }^{15}$

Kriteria diatas, antara satu dengan lainnya, terkadang saling berhubunggan. Kosakata pupuler misalnya mungkin lebih bermanfaat, akan tetapi, pada waktu yang sama siswa mungkin jauh

${ }^{14}$ Uril Bahruddin, Bisa Bahasa Arab Bukan Hannya Mimpi, ( Sukohrajo: Tartil Institut, 2016, cetakan I), h.120.

${ }^{15}$ Muhamd Ali Al-Khuli, Strategi Pembelajaran Bahasa, h. 99. 
lebih memerlukan kosakata yang berkaitan dengan lingkungannya. Sementara kriteria kemudahan bisayanya kontradiktif dengan kriteria lainnya.

Dijelaskan oleh Muhamad Ali Al-Khuli seputar langkah-langkah yang harus disiapkan dalam pembelajaran kosakata baru, sebagai berikut:

a) Guru mengucapkan kata sebanyak dua atau tiga kali dan siswa mendengarkannya.

b) Guru menulis kata di papan tulis dengan harakat lengkap.

c) Guru menjelaskan makna kata dengan cara yang paling sesuai dengan karakter kata tersebut.

d) Guru menggunakan kata tersebut dalam satu atau beberapa kalimat sempurna agar siswa lebih memahami makna dan fungsi gramatikalnya.

e) Siswa menirukan pengucapan salah satu kalimat tersebut kepada siswa, lebih-lebih jika kata tersebut memiliki tingkat kesulitan penulisan.

f) Guru menulis makna kata dan kalimat yang dapat membantu kejelasan makna di papan tulis.

g) Siswa menulis kosakata-kosakata baru yang sudah ditulis di papan tulis.

h) Siswa menulis kata, arti kata, dan contoh kalimat di buku masing-masing. ${ }^{16}$

\section{Strategi Pembelajaran Kosakata Bahasa Arab bagi non Arab}

Pembelajaran kosakata bahasa Arab dapatdilakukan dengan berbagai strategi permainan bahasa, misalnya dengan perbandingan,

${ }^{16}$ Muhamd Ali Al-Khuli, Strategi Pembelajaran Bahasa, h. 103. 
memperhatikan susunan huruf, penggunaan kamus dan lainnya. Pembelajaran ini bisa digunakan dengan berbagai metode yang antara lain yaitu metode secara langsung, metode meniru dan menghafal, metode Aural-Oral Approach, metode membaca, metode GramatikaTranslation, metode pembelajaran dengan menggunakan media kartu bergambar dan alat peraga serta pembelajaran dengan nyanyian.

Selain itu, pembelajaran kosakata bahasa Arab ini dimulai dengan kosakata dasar yang tidak mudah berubah, seperti halnya istilah kekerabatan, nama-nama bagian anggota tubuh, kata ganti, kata kerja pokok serta beberapa kosakata lain yang mudah untuk dipelajari.

Ada tiga prinsip yang harus diperhatikan kitika dalam penyajian kosakata bahasa Arab bagi non Arab. Tiga prinsip tersebut adalah: (a) frequensi yaitu frequensi menggunakan kata-kata yang sering digunakan itulah yang dipilih. (b) coverage yaitu kemampuan suatu kata untuk mencakup beberapa arti kata-kata yang mempunyai daya cukup inilah yang harus dipilih. (c) Learnability, suatu item atau kata dipilih karena itu mudah dipelajari.

Adapun prinsip-prinsip yang digunakan dalam pembelajaran kosakata bahasa Arab bagi non Arab adalah sebagai berikut:

a) Tatawur( Frequency) artinya memilih mufradat (kosakata) yang sering digunakan.

b) Tawazzu' (Range) artinya memilih koskata yang banyak digunakan di negara-negara Arab, yakni tidak hanya banyak digunakan di sebagian negara Arab.

c) Mataahiyyah (Avalability) artinya memilih kata tertentu dan bermakna tertentu pula, yakni kata-kata yang digunakan dalam bidang-bidang tertentu. 
d) Ulfa(Familiarity), artinya memilih kata-kata yang familiyer dan terkenal serta meninggalkan kata-kata yang jarang terdengar penggunaannya

e) Syumul (Coverege), artinya memilih kata-kata yang dapat digunakan dalam berbagai bidang tidak terbatas pada bidang tertentu. Contohnya kata ييت منزل lebih baik dipilih dari pada karena penggunanya lebih umum.

f) Ahammiyah, artinya memilih kata-kata yang sering dibutuhkan penggunaannya oleh siswa dari pada kata-kata yang terkadang tidak dibutuhkan atau jarang dibutuhkan.

g) 'Uruubah, artinya memilih kata-kata Arab, yakni memilih kata Arab walapun ada bandinganya dalam bahasa lain.

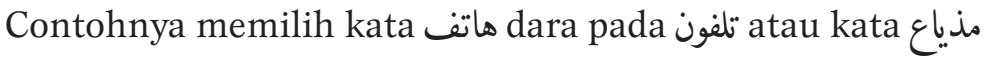
dari pada kata راديو dan lain-lainya. ${ }^{17}$

Berikut ini beberapa strategi yang dapat digunakan guru untuk menjelaskan arti kosakata (bahasa Arab) dan sekaligus dapat dijadikan sebagai barometer kemampuan siswa dalam pengusaan makna kosakata bahasa Arab:

1) Mendengarkan kata, ini adalah strategi pertama. Siswa mendengarkan kata yang diucapkan oleh guru, baik terdiri dari susunan kalimat ataupun berdiri sendiri. Dengan menggunakan tiga maupun empat kali penggulanggan tentunya dengan memperhatikan unsur bunyi dari kata tersebut yang sudah dikuasai siswa, siswa telah mampu mendengarkan secara tepat.

2) Mengucapkan kata, strategi berikutnya adalah memberikan kesempatan seluas-luasnya kepada siswauntuk mengucapkan

${ }^{17}$ Bisri Mustafa dan Abdul Hamid, Metode\&Strategi Pembelajaran Bahasa Arab, h. 69. 
kata yang telah didengarnya. Tujuan dari penggucapkan kata baru membatu siswa dalam ketahan menghafal dalam tempo waktu yang lama. Guru dituntut untuk memperhatikan keakuratan lafal dengan teleti. Karena kesalahan dalam lafal dapat mengakibatkan kesalahan dalam penulisan.

3) Menggunakan isyarat ataupun tanda yang dimaksud secara langsung. Misalnya benda-benda yang ada dalam kelas, alatalat tulis, halaman dan area sekolah, termasuk juga anggota badan guru dan gerak tubuh guru. Benda-benda tiruan maupun sampelnya yang bisa memungkinkan dibawa ke ruang kelas, misalnya alat komunikasi, alat trasportasi, dan macam-macam hewan. Benda-benda seperti tiket, uang, kartu identitas, yang memungkinkan untuk dibawah ke dalam kelas.

4) Dengancaramemperagakan.Seoranggurudapatmenunjukan makna kosakata yang akan diajarak kepada siswanya dengan memperagakan, seperti guru memperagakan orang yang sedang sakit, tertawa, berbicara, duduk, nangis, dan masih banyak lagi.

5) Menggunakan bantuan gambar. Benda yang dimaksud tidak mungkin untuk dihadirkan di dalam kelas, gambar ini berfungsi untuk memperjelas suatu kata baik gambar itu bergerak ataupun permanen, misalnya gambar peta geografis yang sangat tepat untuk mengajarkan zharaf makan, jihat (arah mata anggin) dan kondisi cuaca. Bentuk-bentuk gambar berupa flash card atau gambar berangkai; bisa foto, guntingan koran dan majalah atau gambar tanggan. 
6) Dengan cara memasukan kosakata yang diajarkan dalam kalimat. Contohnya kata جيد maka kata tersebut dimasukan هذا هيد الكّب جيد dalam kalimat

7) Dengan cara menyebutkan kelompok katanya, misalnya الأسرةangan menyebutkan maupun menjelaskan makna kata guru diberkenakan untuk menyebutkan kata berikutnya dan lain sebagainya.

8) Dengan cara mendefinisikan kosakata yang hendak disampaikan (ta'rif). Yaitu dengan menjlesakan arti kata dengan catatan yang digunakan untuk mendefinisikan tersebut familiyer dan dipahami oleh peserta didik maka hal tersebut lebih efektif. Akan tetapi jika kata dan ungkapan yang dipakai untuk mendefinisikan itu lebih rumit dan susah, maka tidak ada gunanya, bahkan lebih membingungkan peserta didik.Contohnya حوت adalah binatang laut yang paling besar. الطائر adalah hewan yang mempunyai dua sayap yang berfungsi untuk terbang.

9) Menggunakanantonim (lawan kata) yang berfungsi untuk memperjelas bila mana kata tersebut sudah dipelajari oleh siswa sebelumnya. Contohny:

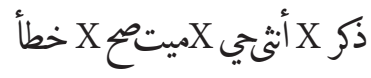

10) Al-siyaq (kontekstual) untuk menarangkan arti misalnya, makna konteks kata kepala (رأس). Huruf al-jar dan af'al asysyuru:

11) Al-silmu al-dalali (tingkatan makna),contoh: سهل، صعب، حار... وبارد.

12) Al-tamtsil (perumpaman) contohnya:

13) Sinonim (persamaan kata) dengan ketentuan kata yang diterangkan maknanya memiliki sinonim dan sudah 
familiyer dikalangkan peserta didik, yang berfungsi menjelaskan makna kata tersebut. Contohnya: - التيفون الهاتف - المحمول أوالكميوتير - الحاسوب. . . .

14) Al-isytiqaq (derivasi) yaitu menyebutkan kata dasar dan kata bentuknya.

contohnya: .... مدرسة - درس- كاتب - كتب

15) Al-tasalsul (menggunakan rangkain-rangkain kata maupun رضيع - طفل - صبيّ- شاب- رجل - شيخ. الروضة، :kalimat) contohnya الأساس، الثنوية، الجامعة

16) Mencari makna kata dengan bantuan kamus. Baik dengan kamus ekabahasa, dwibahasa, dan multibahasa.

17) Menggunakan terjemah, menjelaskan makna kata dengan cara terjemah adalah cara yang paling mudah, akan tetapi mengandung beberapa kelemahan. Antara lain bisa menggurangi sepontanitas peserta didik, lemah daya lekatnya dalam inggatan peserta didik, dan tidak semua kosa kata dalam bahasa Arab terdapat padanya yang tepat dalam bahasa Indonesia. Oleh karenanya penerjemahan diusulkan sebagai cara terakhir, kecuali untuk kata-kata yang abstrak atau sulit diperagakan.

\section{G. Kesimpulan}

Dari pemaran diatas dapat disimpulkan terdapat beberapa strategi dalam penyampaian kosakata bahasa Arab dari guru kepada siswa. Strategi terjemah merupakan startegi yang paling rendah, hendaknya seorang guru menghindari untuk menggunakan strategi ini. Sedangkan strategi yang paling ideal adalahdengan isyarat ataupun tanda yang dimaksud secara langsung.Tentu ada sekala prioritas dalam penyampaikan kosakata bahasa Arab yaitu dimulai dari isim (kata benda) dikarena dalam isim 
tidak banyak perubahan.Kemudian dilanjutkan dengan fi'il (kata kerja), karena terdapat kata kerja bentuk pertama, bentuk kedua, bentuk ketiga, dan seterusnya. Tujuan dari strategi pembelajaran kosakata ini membatu siswa untuk menerjemahkan bentuk-bentuk kosakata dan mampu menggunakanya dalam bentuk jumlah (kalimat) dengan tepat.Dalam artian yang luas siswa tidak hanya dituntut untuk menghafal kosakata tanpa mengetahui penggunannya dan fungsinya dalam komunikasi. Tujuan akhir dari strategi pembelajaran kosakata bahasa Arab ini siswa diajarkan untuk menggunakannya baik dalam bentuk ucapan maupun tulisan. Seorang guru harus menyiapkan dan memperhatikan kosakata yang tepat bagi siswa-siswanya di semua jenjang pendidikan.Oleh karenanya seorang guru harus berpegang teguh pada prinsip-prinsip dan landasan-landasan yang sudah digariskan.Pemilihan kosakata yang tepat merupakan hal yang harus diperhatikan untuk mengungkapkan makna yang dikehendaki.Strategi pembelajaran koskata berkaitan erat dengan penguasaan makna kata-kata, disamping kemampuan penggunannya pada konteks yang tepat dan tempat yang tepat pula.Penguasan kosakata dapat dipetakan menjadi penguasaan yang aktif produktif dan yang pasif reseptif.

\section{DAFTAR PUSTAKA}

Abdul Hamid, Mengukur Kemampuan Bahasa Arab untuk Studi Islma, Malang: UIN Malik Press, cetakan I, 2010.

Acep Hermawan, Metodologi Pembelajaran Bahasa Arab, Bandung: Remaja Rosdakarya, 2014.

Ahmad Fuad Efendy, Metodologi Pengajaran Bahasa Arab, Malang: Miskat,cetakan V 2012. 
Bisri Mustafa dan Abdul Hamid, Metode\&Strategi Pembelajaran Bahasa Arab, Malang: UIN Malang Press,Cetakan II, 2012.

Dep Dik Bud,Kamus Besar Bahasa Indonesia, Jakarta: Balai Pustaka, cetakan III, 1990.

Edison de Cunha, Developing English Teaching Materials For Vocabulary of First Grade of Junior High School.

Hans Wehr, A, Dictionary of Modern Written Arabic, Arabic-English, Beirut: Makatabah Lubnan, cetakan III.

Muhbib Abdul Wahab, Pemikiran Lingustik Tammam Hassan dalam Pembelajaran Bahasa Arab, Jakarta: UIN Jakarta Press, 2009.

Muhbib Abdul Wahab, Epistemologi dan Metodologi Pembelajaran Bahasa Arab, Jakarta: Lembaga Penelitian UIN Syarif Hidayatullah Jakarta, cetakan I, 2008.

Muhamd Ali Al-Khuli,Strategi Pembelajaran Bahasa,Yogyakarta: Bansam Publishing, 2010.

Uril Bahruddin, Bisa Bahasa Arab Bukan Hannya Mimpi, Sukohrajo: Tartil Institut,cetakan I, 2016.

Zulhanan, Teknik Pembelajaran Bahasa Arab Interaktif, Depok: Raja Grafindo Persada,cetakan I, 2014. 